\title{
Do Regulations Matter in Fighting the COVID-19 Pandemic? Lessons from Poland
}

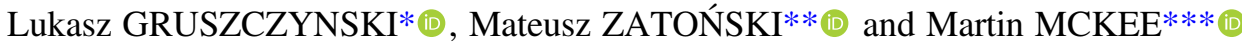

In this article, we argue that the design and timing of regulatory responses, as well as the adherence of the population to the relevant rules, have a critical impact on the progression and public health consequences of the COVID-19 pandemic. This hypothesis is empirically tested using the example of Poland, a country that experienced, compared to its Western European neighbours, a relatively mild first phase of the pandemic. In this context, we compare Poland with selected countries, including France, Germany, Spain and the UK, and we supplement them with examples from other Visegrad Four (V4) countries - Czechia, Slovakia and Hungary. On that basis, we conclude that while the observed differences between the countries in the progression of the COVID-19 pandemic are the result of a multitude of complex and interrelated reasons (such as demographic structure, population density and connectivity or cultural factors), well-designed public health measures, which are implemented early as a part of the proactive strategy that anticipates and reacts quickly to changing circumstances, can effectively decrease the number of COVID-19 infections and related deaths, provided that the adherence of the relevant population is high.

\section{INTRODUCTION}

Epidemiologists have long warned that another pandemic was inevitable, ${ }^{1}$ and, when it came, it could kill millions. ${ }^{2}$ In 2018, the World Health Organization (WHO), seeking to raise awareness of the need for preparedness, coined the term "Disease $\mathrm{X}$ " to represent a hypothetical illness with pandemic potential. ${ }^{3}$

\footnotetext{
* Associate Professor, Law School, Kozminski University, Poland and Research Fellow, Centre for Social Sciences, Institute for Legal Studies, Hungary email: lgruszczynski@kozminski.edu.pl.

** Research Fellow, Department for Health, University of Bath, UK and Adjunct Professor, European Observatory of Health Inequalities, Calisia University, Poland; email: mzz27@bath.ac.uk.

*** Professor of European Public Health, London School of Hygiene and Tropical Medicine, UK; email: Martin. McKee@1shtm.ac.uk.

1 L Garrett, The Coming Plague: Newly Emerging Diseases in a World Out of Balance (New York, Farrar, Straus and Giroux 1994).

2 See Centre for the Study of Existential Risk, Global Catastrophic Biological Risks, available at <https://www.cser. ac.uk/research/global-catastrophic-biological-risks/> (all Internet sources last accessed on 18 October 2021).

3 WHO, "Prioritizing diseases for research and development in emergency contexts", available at $<$ https://bit.ly/ 3nIQJM2>.
} of the Creative Commons Attribution licence (https://creativecommons.org/licenses/by/4.0/), which permits unrestricted reuse, distribution, and reproduction in any medium, provided the original work is properly cited. 
Despite these warnings, the global spread of COVID-19 came as a surprise to many. Few countries reacted rapidly, and national regulatory responses were poorly designed and coordinated. Initial efforts to contain SARS-CoV-2 in China failed, and the virus spread quickly to other parts of the world. At the end of January 2020, the WHO classified COVID-19 as a Public Health Emergency of International Concern, and in March 2020 as a pandemic. As of 18 October 2021, there were more than 241 million registered cases worldwide and almost 5 million COVID-19-related deaths. Many infections have not, however, been detected, and the true death toll is likely higher. For example, it was estimated in May 2021 that the death toll was between 7.1 and 12.7 million, with a central estimate of 10.2 million. ${ }^{4}$ By now, this number is likely higher.

Yet some countries have been more successful in controlling the pandemic, managing to keep the number of new infections and COVID-19 deaths low. New Zealand, Singapore, South Korea, Taiwan and Australia are conventionally identified as the leaders. ${ }^{5}$ On the other hand, the initial success of the Visegrad Four (V4) countries (ie Czechia, Hungary, Poland and Slovakia) has received less attention in the international media and academic literature. ${ }^{6}$ This is surprising as all four countries have seen much lower numbers of COVID-19 cases and related deaths in the first phase of the pandemic than their Western European peers or countries from South and North America. Although this picture has changed as the pandemic has continued to unfold, it remains clear that its first phase was relatively mild in the V4 region.

Public authorities can use different regulatory measures to control the spread of infectious diseases. ${ }^{7}$ One set of measures seeks to reduce the opportunities for the virus to spread within the population. These come under the broad term "social distancing" and include closure of places where people gather indoors and rules to reduce people mixing closely together. Another set of measures seeks actively to reduce transmission by those infected, with testing conducted to identify them, tracing of contacts and isolation of those suspected or known to be infected. ${ }^{8}$ As uncontrolled infections increase exponentially, in both cases early action is essential. ${ }^{9}$ Once the decision is made to adopt these measures, governments can impose them

\footnotetext{
4 "There have been 7m-13m excess deaths worldwide during the pandemic" (Economist, 15 May 2021), available at $<$ https://econ.st/3Bc7Hcp > ; see also FP Havers et al, "Seroprevalence of antibodies to SARS-CoV-2 in 10 sites in the United States, March 23-May 12, 2020” (2020) 180(20) JAMA Internal Medicine 1576.

5 See, eg, I Bremmer, "The best global responses to COVID-19 pandemic" (Time, 12 June 2020), available at $<$ https://time.com/5851633/best-global-responses-covid-19/>.

6 Of course, there some exceptions; see, eg, J Shotter and S Jones, "How Central and Eastern Europe contained coronavirus?" (Financial Times, 30 April 2020), available at $<$ https://www.ft.com/content/f9850a8d-7323-4de593ed-9ecda7f6de1c>; J Culik and M Solic, "Why don't we hear about the low number of coronavirus deaths in Central Europe?" (The Conversation, 26 June 2020), available at $<$ https://theconversation.com/why-dont-we-hearabout-the-low-number-of-coronavirus-deaths-in-central-europe-141148>; M McKee, "Learning from success: how has Hungary responded to the COVID pandemic?", (2020) 42(5) Geroscience 1217.

7 RP Walensky and C del Rio, "From mitigation to containment of the COVID-19 pandemic: putting the SARS-CoV2 genie back in the bottle" (2020) 323(19) JAMA 1889.

8 OECD, "Flattening the Covid-19 peak: Containment and mitigation policies", updated 24 March 2020, available at $<$ https://bit.ly/2TCqV7d $>$.

9 ECDC, "Guide to public health measures to reduce the impact of influenza pandemics in Europe", 2009, available at $<$ https://bit.ly/34BriFo $>$.
} 
with differing degrees of compulsion, from non-mandatory guidance to the use of legal sanctions.

In this article, we argue that the design and timing of regulatory responses, as well as the adherence of the population to the relevant rules, have a critical impact on the progression and public health consequences of the COVID-19 pandemic. This claim is tested using the example of Poland, a country that experienced, compared to its Western European neighbours, a relatively mild first phase of the pandemic. In this context, we compare Poland with selected Western European countries, including neighbouring Germany, which is widely seen as performing well during that phase of the pandemic. ${ }^{10}$ Where appropriate, we also bring in examples from other V4 countries, which saw similar developments to what was observed in Poland. On that basis, we draw some general conclusions regarding the characteristics of the optimal regulatory strategy for managing the pandemic.

\section{Methodological COnsiderations And Limitations of the StUdy}

We conducted a systematic analysis of the Polish regulatory response to the initial phase of the pandemic, seeking to identify its legal and societal characteristics. We focus on the timing of Poland's regulatory response, its design and the level of adherence by the Polish population, looking at these elements against the experience of other countries (ie France, Germany, Spain, the UK and other V4 states). We chose European states of comparable size to Poland but eliminated Italy, as the surprise factor had had a clear impact on its reaction to the pandemic. Other V4 countries were taken into account due to their existing similarities, both in terms of the progression of their epidemics and their regulatory responses. Next, with reference to these three elements, we attempted to explain why Poland's initial success descended into a full-fledged public health crisis in October 2020-March 2021.

Data on COVID-19 cases and deaths have been taken, unless stated otherwise, from the COVID-19 Coronavirus Pandemic database run by Worldometer. ${ }^{11}$ Details of how these data are collected, analysed and validated are available on its webpage. ${ }^{12}$ Data on mobility were obtained from the COVID-19 Projections models developed by the Institute for Health Metrics and Evaluation (IHME). ${ }^{13}$ The same source was used to obtain data on face mask use (expressed as a percentage of the population who say they always wear a face mask in public), which are based on information from Premise; Facebook Global symptom survey, Facebook US symptom survey; the Kaiser Family Foundation; and the YouGov COVID-19 Behaviour Tracker survey. We also used the Government Response Stringency Index (GRSI) developed at the University of Oxford. ${ }^{14}$ This is a composite measure based on nine response

10 L Wieler, U Rexroth and R Gottschalk, "Emerging Covid-19 success story: the challenge of maintaining progress" (Exemplars in Global Health), available at $<$ https://bit.ly/35TbSwM $>$.

11 See $<$ https://www.worldometers.info/coronavirus/>.

12 See $<$ https://www.worldometers.info/coronavirus/about/>.

13 See $<$ https://covid19.healthdata.org/>.

14 T Hale et al, Oxford COVID-19 Government Response Tracker (Oxford, Blavatnik School of Government 2020). 
indicators including school closures, workplace closures and travel bans, rescaled to a value from 0 to $100(100=$ strictest $)$.

Our analysis covers the first five months of the pandemic in each country, starting on the day when the first case of local transmission was confirmed. This date was chosen to avoid problems arising from the scatter of imported cases, which dominated the beginning of the pandemic. Although the choice of a five-month reference period may be seen as arbitrary, it covers the first phase of the pandemic, characterised by initial exponential growth, followed by a peak (albeit at different levels) and steady decline in the number of daily cases, with stabilisation at the low levels.

It is important to highlight two limitations in this study. First, there are significant differences between the V4 and Western European countries as far as testing for coronavirus is concerned. Generally, the V4 states, including Poland, have performed fewer tests than their Western European peers. For example, as of 21 November 2020, Poland had performed only 155,992 tests per million inhabitants, Hungary 153,427 and Slovakia 185,020, while Czechia undertook 271,093. Meanwhile, Germany performed 315,378 tests per million, France 302,763 and the UK as many as 591,923 (these proportions have not change much to date). Of course, less extensive testing likely means that more cases have gone undetected.

Second, there are also differences in the ways individual countries legally classify COVID-19-related deaths. ${ }^{15}$ For example, Poland requires as a prior positive test result to qualify a particular death as COVID-19-related and there is no post-mortem testing. On the other hand, Belgium has included in its statistics those patients who died while exhibiting symptoms of the disease (without a need for confirmatory testing). These differences may lead to figures that are either over- or underestimates. However, it should be stressed that the disparities between Poland (as well as the other V4 countries) and its Western European peers are so large in the analysed period (particularly when it comes to the number of COVID-19 deaths) that they cannot be explained solely by differences in testing and reporting. Moreover, during the first phase of the pandemic, the V4 countries did not experience any significant excess of mortality. Their mortality rates ranged from possible small declines to increases of $5 \%$ or less in either sex, similar to countries such as New Zealand or Australia. ${ }^{16}$ On the other hand, almost all Western European countries saw strong increases from their pre-existing mortality trends. ${ }^{17}$

\section{The COVID-19 PANDEMIC AND THE REgulAtory RESPONSE}

\section{Epidemiology of COVID-19 in Poland}

SARS-CoV-2 arrived in Poland later than in Western Europe but at around the same time as in other V4 countries. The first case was identified on 4 March 2020, about a month

\footnotetext{
15 C Hirsch and C Martuscelli, "The challenge of counting COVID-19 deaths" (Politico, 30 April 2020), available at $<$ https://www.politico.eu/article/coronavirus-the-challenge-of-counting-covid-19-deaths/>.

16 V Kontis et al, "Magnitude, demographics and dynamics of the effect of the first wave of the COVID-19 pandemic on all-cause mortality in 21 industrialized countries" (2020) 26 Nature Medicine 1919.

17 ibid. See also data compiled by The Economist: "The covid-19 pandemic is worse than official figures show" (The Economist, 26 September 2020), available at <https://www.economist.com/briefing/2020/09/26/the-covid-19pandemic-is-worse-than-official-figures-show $>$.
} 
after France and Germany. The patient was a sixty-six-year-old man who had returned from a visit to Germany. Close contacts of the patient were quarantined and several tested positive in the subsequent days. The first local transmission - involving someone infected on the territory of Poland ${ }^{18}$ - was registered on 10 March. $^{19}$ The peak of the first phase of the pandemic occurred on 8 June 2020 (in terms of number of registered new cases - 599) or 17 June 2020 (in terms of number of active cases -14,474). The number of daily infections started to grow at the end of July but declined again after about a month. Incidence grew once again from mid-September, and rapidly so from 7 October 2020. Since then, Poland has seen an increasing number of cases and COVID-19-related deaths. The highest number of new cases during the second wave was registered on 7 November 2020 (27,875), while deaths peaked on 19 November 2020 (637). Even higher numbers were recorded during the third wave (February-May 2021), with a peak of 35,246 cases per day and 954 deaths. A similar pattern could be observed in the other V4 countries.

Notwithstanding the later deterioration, the initial phase of the pandemic in Poland was very mild as compared to most Western European states. Table 1 presents data on the cumulative number of infections, cases per million, death toll and deaths per million in the V4 countries and selected countries of Western Europe.

\section{The regulatory response to the first phase of the COVID-19 pandemic in Poland}

The Polish government quickly enacted a series of strict public health measures designed to limit the spread of the virus. Initial voluntary recommendations rapidly gave way to command-and-control measures (except for those related to individual hygiene, which remained only as guidance). These efforts were coupled with a gradual intensification of laboratory testing (the first testing centres were established in March 2020, increasing thereafter), contact tracing, quarantining and monitoring of those isolating. Although Poland has never come close to the levels of effectiveness in testing and tracing seen in some Western European countries, this deficiency was compensated in the first phase of the pandemic by other restrictions. Most of the measures introduced during that time had a proactive rather than reactive character. A detailed timeline of regulatory actions taken by the Polish government is presented in Table 2.

Although most of these measures were not unique to Poland, in their totality they constituted a particularly strict and wide-ranging regime compared to Western European countries. The restrictions were also introduced very early, with social distancing requirements virtually from the beginning. The first cases of COVID-19 in Poland were recorded on 4 March 2020, while the first restrictions were imposed on $10 \mathrm{March}$, when Poland only had twenty-two cases and no registered deaths. Although the initial restrictions were mild, they were quickly tightened (eg on 12, 15 and $24 \mathrm{March}$ ), culminating in a comprehensive lockdown by 24 March 2020. At that time, there were

\footnotetext{
18 Local transmission should be distinguished from community transmission. The latter means an infection that occurred on the territory of a specific country when the source of the infection has not been found.

19 WHO, "Coronavirus disease 2019 (COVID-19) Situation Report - 50" (10 March 2020), available at <https:// www.who.int/docs/default-source/coronaviruse/situation-reports/20200310-sitrep-50-covid-19.pdf>.
} 
Table 1. Number of infections and deaths in selected European countries in the first phase of the COVID-19 pandemic.

\begin{tabular}{lccrrr}
\hline Country & Number of infections (cumulative) & Cases per million & Number of deaths & Death per million & Period \\
\hline Slovakia & 2417 & 447 & 29 & 5 & 6 March-5 August 2020 \\
Hungary & 4593 & 478 & 534 & 55 & 7 March-6 August 2000 \\
Czechia & 17,523 & 1637 & 388 & 36 & 6 March-5 August 2020 \\
Poland & 51,791 & 1370 & 1807 & 47 & 10 March-9 August 2020 \\
France & 164,260 & 2515 & 30,238 & 463 & 30 January-29 June 2020 \\
Germany & 194,399 & 2319 & 8273 & 98 & 27 January-26 June 2020 \\
Spain & 272,394 & 5832 & 28,327 & 606 & 25 February-24 June 2020 \\
UK & 279,019 & 4109 & 40,170 & 591 & 26 February-25 June 2020
\end{tabular}

Source: Worldometer statistical database, own calculations by the authors. 
Table 2. Timeline of regulatory actions introduced in Poland in the first phase of the COVID-19 pandemic.

\section{Date}

7 March 2020

8 March 2020

9 March 2020

10 March 2020

12 March 2020

15 March 2020

24 March 2020

1 April 2020

16 April 2020

20 April 2020

4 May 2020

18 May 2020

30 May 2020

13 June 2020

\section{Regulatory measure(s)}

Recommendation of the Chief Sanitary Inspector (CSI) discouraging travel to Hong Kong, South Korea, Iran, Japan and Italy

Recommendation of the CSI for cancellation of mass events (over 1000 participants indoors)

Introduction of sanitary controls at the Polish borders

Cancellation of all mass events (over 1000 participants outdoors and over 500 participants indoors)

Closure of all schools, universities, kindergartens and cultural institutions (eg operas, theatres, cinemas and museums)

Closure of international borders (Polish citizens were admitted but needed to quarantine); prohibition of public gatherings and religious services and funerals restricted to 50 participants; closure of restaurants and shopping centres

limited mobility allowed

Closure of public places such as parks, closure of hotels and some service points (eg hairdressers); minors prohibited from leaving their homes unaccompanied; additional safety requirements in shops

Obligatory face masks in public places

The first phase of easing the restrictions (eg removing restrictions on mobility, increased limits of individuals in shops and churches, recreational outside activities permitted, forests and parks reopened)

The second phase of easing restrictions (eg conditional opening of shopping centres, cultural institutions, kindergartens and accommodation and tourism establishments)

The third phase of easing the restrictions (eg opening of many service outlets, including restaurants for in-dining services, open air sport events with limited audience permitted); reopening of schools and universities (from 24 May)

The fourth phase of easing the restrictions (eg further easing for restaurants, bars, sport events and religious sites); modification of the face mask requirement (eg obligatory on public transport, in shops and in churches); reopening of cinemas, theatres, swimming pools, fitness clubs, etc. (from 6 June)

Source: Government Centre for Security (https://rcb.gov.pl/en/), own compilation by the authors. 
only 890 COVID-19 cases and ten registered deaths in the country. Thus, Poland effectively instituted a lockdown within eighteen days from the first diagnosed coronavirus case and fourteen days from the first local transmission. The difference is striking when one compares this timeline with those of many Western European countries. Spain's lockdown was declared on 14 March 2020, ${ }^{20}$ when the country already had 46,652 diagnosed COVID-19 cases and 196 deaths. France's lockdown was declared on 17 March 2020, when the country had 6953 recorded COVID-19 cases and 175 deaths. The UK's lockdown came into effect on 23 March 2020, with 6030 diagnosed COVID-19 cases and 331 deaths (which suggests that the number of actual cases was much higher). Germany was the only country that did not introduce any nationwide lockdown. Instead, on 22 March 2020, it imposed strict social distancing measures, with only two Lands opting for lockdowns. ${ }^{21}$ At that time, Germany had 24,873 registered cases and ninety-four COVID-19-related deaths. On the other hand, other V4 countries adopted similar approaches to that of Poland. Czechia and Slovakia introduced full lockdowns on 16 March 2020 (384/0 and 72/0 cases/deaths, respectively), ${ }^{22}$ while Hungary did so on 28 March (343/11 cases/deaths). ${ }^{23}$

In several respects, the Polish government decided to go beyond international good practice and apply measures that were not recommended by international institutions and whose effectiveness only became accepted later. For example, on 16 April 2020, Poland made the wearing of face masks mandatory in all public places. This was defined broadly to include not only public transport, public buildings and shops, but also streets and workplaces. ${ }^{24}$ In the UK, the government only advised people to wear face coverings on 1 May and mandated face masks on public transport on 15 June and in shops and supermarkets on $24 \mathrm{July}^{25}$ France was equally late, as it required people to wear face masks starting from 11 May (schools and public transport) and 20 July (indoor spaces). ${ }^{26}$ In Spain, this obligation was introduced on 4 May (on public transport and in all public spaces - both open and closed - where social distancing is not possible). ${ }^{27}$ Germany was earlier; the nationwide requirement (covering travelling on public transportation and while shopping) was introduced on 27 April 2020, when the country had 158,758 identified cases and 6126 deaths. The WHO only issued its non-binding recommendations on wearing masks in public

\footnotetext{
20 S Jones, "Spain orders nationwide lockdown to battle coronavirus" (Guardian, 14 March 2020), available at $<$ https://bit.ly/3mAIm4r>.

21 "Coronavirus: what are the lockdown measures across Europe?" ( $D W, 14$ April 2020), available at <https://bit.ly/ 3mwj9Ir $>$.

22 Government of the Czech Republic, "Measures adopted by the Czech Government against the coronavirus" (27 October 2020) available at <https://bit.ly/3oAyo4W>; Government of the Slovak Republic, "Adopted measures" (undated) available at $<$ https://korona.gov.sk/en/adopted-measures/ $>$.

23 Z Kovacs, "Hungary goes into lockdown against coronavirus" (Index, 27 March 2020), available at <https://bit.ly/

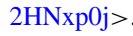

24 Regulation of the Council of Ministers of 15 April 2020 amending the regulation establishing certain restrictions, orders and prohibitions related to the state of epidemic, Official Journal 2020, item 673, para 4.

25 British Government, "Face coverings to become mandatory on public transport" (4 June 2020), available at $<$ https://bit.ly/3ozQWSU>.

26 "Coronavirus: France mandates masks for schools and transport" (BBC News, 28 April 2020), available at <https:// www.bbc.com/news/world-europe-52459030>.

27 EG Sevillano, "Face masks in Spain will be compulsory in public spaces where social distancing cannot be respected" (El Pais, 19 May 2020), available at <https://bit.ly/3e0xSIR >.
} 
spaces on 5 June $2020 .{ }^{28}$ Since then, the requirement has become a globally accepted standard. ${ }^{29}$

Poland was also one of the first European Union (EU) countries to decide to shut down its external borders, including those with other EU Member States. This was done despite opposition from the European Commission, which earlier also rejected the idea of reestablishing border controls with Italy (arguing that it was too early for such a move that went against one of the fundamental freedoms), ${ }^{30}$ and it later warned Member States against imposing unilateral travel restrictions. As summarised by the President of the Commission Ursula von der Leyen in her speech on 12 March 2020 (ie two days after the Polish borders were closed for foreigners), "[C]ertain controls may be justified, but general travel bans are not seen as being the most effective by the World Health Organization. ... Moreover, they have a strong social and economic impact, they disrupt people's lives and business across the borders". ${ }^{31}$ Indeed, at that time the WHO did not recommend such restrictions. For example, in its advice from 29 February 2020, the WHO stated that it "continues to advise against the application of travel or trade restrictions to countries experiencing COVID-19 outbreaks". ${ }^{32}$ As with face mask wearing, there is now evidence supporting strict border controls, and such controls are attracting growing support as a pandemic response measure. ${ }^{33}$

These early interventions in Poland reduced the mobility of the population, with a marked reduction in economic and social life. However, the drop in mobility, as measured by mobile phone data, was much smaller in Poland, and in the other V4 countries, than in Western Europe. For example, for Poland, the maximum divergence from typical mobility was 55\% (13 April), and for Hungary it was only 43\% (23 March). In France we saw an 85\% reduction, in the UK $70 \%$ (31 March), Spain $83 \%$ (4 April) and Germany 56\% (26 March). ${ }^{34}$ However, what was different was the time when mobility started to decrease. Although this happened at around the same time in all of the countries we reviewed (between 5 and 10 March), all V4 countries were still in the initial phase of their epidemics, while the Western European countries already had significant levels of community transmission.

\footnotetext{
28 WHO, "Advice on the use of masks in the context of COVID-19. Interim guidance" (5 June 2020), WHO/2019nCov/IPC_Masks/2020.4.

29 See, eg, S Asadi et al, "Efficacy of masks and face coverings in controlling outward aerosol particle emission from expiratory activities" (2020) 10 Scientific Reports 15665; J Howard et al, "Face masks against COVID-19: an evidence review" (2021) 118(4) Proceedings of the National Academy of Science of the United States of America e2014564118.

30 "Coronavirus: EU rules out Schengen border closures amid Italy outbreak" ( $D W, 24$ February 2020), available at $<$ https://bit.ly/3jAJAuF $>$.

31 M Peel, R Milne and J Shotter, "Denmark, Poland and Czechs seal borders over coronavirus" (Financial Times, 13 March 2020), available at <https://www.ft.com/content/4e89ec5c-6565-11ea-b3f3-fe4680ea68b5>. See generally K Goniewicz et al, "Current response and management decisions of the European Union to the COVID-19 outbreak: a review" (2020) 12(3838) Sustainability 1.

32 WHO, "Updated WHO recommendations for international traffic in relation to COVID-19 outbreak", available at $<$ https://bit.ly/3mlFVmq $>$.

33 R Koopmans, "A virus that knows no borders? Exposure to and restrictions of international travel and the global diffusion of COVID-19”, WZB Discussion Paper, October 2020; M Eckardt, K Kappner and N Wolf, “Covid-19 across European regions: the role of border controls", CEPR Discussion Paper 15178 (2020).

34 IHME, "COVID-19 Projections", available at $<$ https://covid19.healthdata.org/global?view=total-deaths\&tab= trend $>$.
} 
The expediency of the regulatory reaction in Poland is apparent in the GRSI, which makes it possible to compare the strictness and timing of COVID-19-related governmental interventions in different countries. ${ }^{35}$ On 4 March 2020, when the first COVID-19 case was identified in Poland, the GRSI was at the low level of 11.11 points. Six days later it rose to 25 , while on 14 March it was already at 41.67 , reaching 81.48 points by 31 March. On 9 April, the GRSI for Poland moved to 83.33 points (the highest position during the first phase of the pandemic in Poland), and it started to decrease from 25 May 2020.

If one compares this trajectory with those of Western European countries, two things can be observed. Although the ultimate strictness was very similar for all European states, Poland reacted earlier than all Western European countries discussed here. It also moved much faster from an unrestricted regime to a rigorous one. Poland started to strengthen its restrictions substantially (an increase of the initial GRSI of $100 \%$ or more) on the first day of registered local transmission. In France this took thirty days, fourteen days for Spain, twenty days for the UK and thirty-one days for Germany. Moreover, it took Poland only twenty-one days from the detection of the first case of local transmission to advance from almost no restrictions to a very strict sanitary system (above 80 points). In France this took forty-seven days, Spain needed thirty-four days, while the UK and Germany never reached this level. In the UK the highest recorded level was 79.63 points, and this was reached on 24 March 2020, twenty-seven days after the first registered local transmission. Germany reached a peak in stringency of 76.85 points on 22 March 2020, fifty-four days after its first case of local transmission. In contrast, the other V4 countries acted as rapidly as Poland. They introduced restrictions early and increased their stringency over a short period of time. For example, Hungary went from 5.56 to 76.85 points in thirty-two days (but it reached 67.59 points in only seventeen days), while the steepest increase in restrictiveness occurred only four days after the first detected local transmission. ${ }^{36}$

While some of the regulatory measures introduced by the Polish government in March and April 2020 appear to be unnecessarily restrictive (eg a ban on entering forests, an absence of exemptions for people exercising outside their homes, a requirement for physical distancing when outside even with people living in the same household), taken together the measures adopted seemed to be successful in limiting opportunities for transmission of SARS-CoV-2 in the Polish population.

\section{Adherence to COVID-19 regulations during the initial phase of the pandemic in Poland}

Regulatory adherence can be understood as obedience by a target group regarding governmental regulation. The level of adherence depends on three factors. First, the group has to be aware of a rule and understand it (so relevant rules should be formulated in a clear and precise manner). Second, the group needs to be willing to

\footnotetext{
35 Coronavirus Government Response Tracker, available at <https://www.bsg.ox.ac.uk/research/research-projects/ coronavirus-government-response-tracker $>$.

36 ibid.
} 
comply. This can be influenced by "economic incentives, positive attitudes arising from a sense of good citizenship, acceptance of policy goals, or pressure from enforcement activities", 37 such as inspections and sanctions. Third, the target group must be able to comply with a rule in practical terms. In this article, we focus on the second factor in the Polish context.

Poles traditionally have had limited confidence in public institutions, particularly those at the central level. In 2018, only $44 \%$ of Poles reported trusting the government, with $46 \%$ distrusting it. The parliament was only trusted by $34 \%$ of the population. ${ }^{38}$ In a 2017 survey, $39 \%$ of Poles also believed that most ordinary people do not obey the law. ${ }^{39}$ The great majority of Poles (70\%) consider that sanctions for breaking the law are generally insufficient. ${ }^{40}$ Overall, Poles appears to be sceptical about both the good intentions of regulators and existing enforcement mechanisms. This would suggest that adherence to COVID-19 restrictions might have been moderate or low.

In fact, although there are no empirical studies that assessed actual adherence during the first phase of the pandemic, there is some indirect evidence suggesting that adherence levels were relatively high. In April 2020, the majority of respondents (59\%) in the major opinion poll indicated that they consider the epidemic as an extraordinary event. Most Poles $(78 \%)$ also believed that people tend to adhere to restrictions imposed in connection with the pandemic. ${ }^{41}$ In another survey (23-24 March 2020), between $80 \%$ and $87 \%$ of respondents confirmed that they were following the different governmental restrictions. ${ }^{42}$ This high level of (perceived) adherence is confirmed by other polls. For example, in a survey from 24 and 26 March, 82.4\% of respondents reported strictly following public health measures, with only $3.1 \%$ giving a negative answer (14.5\% answering "neither yes nor no"). ${ }^{43}$

Paradoxically, the low level of societal trust (including trust in public institutions and their actions) may also explain the apparent willingness of Poles to adhere to the COVID-19 restrictions. As noted by Maj and Stażyńska, such a lack of trust could constitute a strong motivating factor to implement individual protective strategies (thinking along the lines that "no one will protect me or my loved ones from falling ill if I don't properly take care of protecting against coronavirus[; s]o I have to stay home because that's the only thing I can do for myself"). ${ }^{44}$ This lack of trust has been particularly visible with respect

37 OECD, Reducing the Risk of Policy Failure: Challenges for Regulatory Compliance (Paris, 2000), available at $<$ https://www.oecd.org/gov/regulatory-policy/46466287.pdf>, p 12.

38 CBOS, O nieufności i zaufaniu [About distrust and confidence], No. 35/2018, March 2018, available at <https:// www.cbos.pl/SPISKOM.POL/2018/K_035_18.PDF > .

39 CBOS, Spoteczne oceny wymiaru sprawiedliwości [Societal assessment of the judicial system], No. 31/2017, March 2017, p 2, available at <https://www.cbos.pl/SPISKOM.POL/2017/K_031_17.PDF>.

40 ibid, p 3.

41 CBOS, Opinie o epidemii koronawirusa i zwiazanych z nim restrykcji [Opinions about the coronavirus epidemic and related restrictions], No. 58/2020, May 2020, available at <https://www.cbos.pl/SPISKOM.POL/2020/K_058_20. $\mathrm{PDF}>$.

42 K Hammer, M Baran and M Marchlewska, Psychologia a koronawirus, Część II [Psychology and the coronavirus, Part II], 6 April 2020, available at $<$ https://bit.ly/3mFpTEa $>$.

43 K Maj and K Stażyńska, Społeczeństwo wobec epidemii. Raport z badań [Society faced with the epidemic. Report from the research], Fundacja im. Stefana Batorego, 2020, available at <https://www.batory.org.pl/wp-content/uploads/ 2020/04/Badanie-spoleczenstwo-wobec-epidemii-fin.pdf >.

44 Ibid (own translation by the authors). 
to the national healthcare system. Polls conducted before the pandemic showed that Poles viewed their healthcare system as both underfunded and understaffed ${ }^{45}$ and at risk of being quickly overwhelmed by a sudden increase in serious illness. ${ }^{46}$ It is rational to assume that this perception of imminent crisis might have been an important motivational factor for following rules or accepting far-reaching precautionary measures.

Surveys also found a high level of fear in Polish society during the first phase of the pandemic. As many as $75 \%$ of Poles were afraid of a fast and uncontrolled spread of the disease, $72 \%$ were afraid of infections in one's own social circles and $59 \%$ were afraid of being infected (23-24 March 2020). ${ }^{47}$ The same survey was repeated between 8 and 10 April, finding that the level of the fear had increased as the pandemic unfolded. ${ }^{48}$ Fear is a powerful motivator of behaviour, ${ }^{49}$ although it can also backfire.

Adherence was also incentivised by the system of sanctions introduced by the Polish government to accompany the new restrictions. From 1 April 2020, sanctions were increased significantly. For example, financial penalties for infringement of the quarantine regime were increased six-fold. ${ }^{50}$ The number of people responsible for monitoring compliance was also increased. Spot checks could be conducted not only by officials of local sanitary and epidemiological stations but also by police and territorial defence forces. In fact, according to the Polish media, a relatively small number of violations was reported by the police. ${ }^{51}$

Taken together, it seems that Poles were generally willing to adhere to the restrictions imposed by the government, as they recognised the seriousness of the situation that required unprecedented regulatory responses, even though their level of trust in public institutions was low (or precisely because of it).

Given the different methodologies and incomplete data, it is difficult to compare levels of adherence among European countries. A report prepared by the European Parliament, based on a survey conducted between 23 April and 1 May 2020, found significant differences among citizens of different countries. The levels of satisfaction with the public health measures taken by national governments in the initial phase of the COVID-19 pandemic were low in Spain (35\%), Poland (40\%) and France (42\%) and high in Czechia (65\%) and Germany (66\%), with Hungary and Slovakia somewhere in between (48\% and 54\%, respectively). The levels of trust in governments (as far as

45 CBOS, Opinie na temat funkcjonowania opieki zdrowotnej [Opinions about functioning of healthcare system], July 2018, available at <https://cbos.pl/SPISKOM.POL/2018/K_089_18.PDF>.

46 K Hammer and M Baran, Psychologia a koronawirus, Część IV [Psychology and the coronavirus, Part IV], 20 April 2020, available at $<\mathrm{https} / / / \mathrm{bit} . l y / 3 \mathrm{kMjw} 15>$.

47 K Hammer, M Baran and M Marchlewska, Psychologia a koronawirus, Część I [Psychology and the coronavirus, Part I], 30 March 2020, available at <https://psych.pan.pl/pl/psychologia-a-koronawirus/>.

48 Hammer and Baran, supra, note 46, p 6.

49 C Harper et al, "Functional fear predicts public health compliance in the COVID-19 pandemic" (2020) International Journal of Mental Health and Addiction doi: 10.1007/s11469-020-00281-5.

50 See Regulation of the Council of Ministers of 31 March 2020 establishing certain restrictions, orders and prohibitions related to the state of epidemic, Official Journal 2020, item 566; Act of 31 March 2020 amending the law on the detailed solutions for prevention, counteracting and eradication of Covid-19, other infectious diseases and related crisis situations and some other laws, Official Journal 2020, item 568.

51 See "Ponad 57 tys. Polaków w kwarantannie domowej. 1 na 100 jej nie przestrzega" [More than 57 thousand Poles in home quarantine, 1 in 100 does not comply] (RMF24, 19 March 2020), available at <https://bit.ly/38130XM>; "Ponad 3 miliony kontroli przestrzegania kwarantanny. Nowe dane i apel policji" [More than 3 million quarantine checks. New data and the call from the police] (Polskie Radio 24, 14 April 2020), available at <https://bit.ly/3216ZQi $>$. 
information about the coronavirus pandemic is concerned) were generally low in all of the countries included. On the other hand, people in Western European countries, more frequently than their Central European peers, expressed acceptance of limitations to individual freedoms in the fight against the pandemic. ${ }^{52}$ However, on the basis of the available data, it is not possible to conclude that there were significant divergences in actual adherence between Poland and the other countries included in this article. At the same time, the data do suggest that the wearing of face masks in public was generally much more frequent in the V4 countries than in Western Europe. In Poland, the maximum figure for face mask use during this time period was $78 \%$ (on 29 April 2020), and it remained above $70 \%$ for more than a month (between 14 April and 21 May 2020). Slovakia was even better, as it recorded $91 \%$ face mask use (19 April 2020 and later), and Czechia reported face mask use rates of 83\% (25 April 2020) and Hungary $63 \%$ (19 May 2020). In France, the maximum face mask use level was 44\% (24 May-8 June 2020), the UK only reached 13\% (16 June 2020 and later), while Germany recorded 52\% (24 May 2020 and later). Spain was the best performer, reaching $79 \%$ on 13 June 2020, but this was almost two months later than the adherence peak in the V4 countries. ${ }^{53}$ While one cannot conclude that overall adherence was definitively higher in the V4 countries than in their Western European neighbours, the available data on face masks (which symbolically reflect the obedience) would suggest that this could indeed be the case.

\section{IF IT WAS SO GOOD, WHY HAS IT GONE SO BAD?}

We have reviewed above the regulatory measures taken by the Polish government in the first phase of the COVID-19 pandemic - in particular (1) their design, (2) their timing and (3) adherence by the Polish population. Their design and timing differed significantly from the approach taken in Western European countries. There is also some evidence suggesting that levels of adherence were higher in Poland than in Western European countries. We argue that these differences might help explain the different levels of progression in Poland (and the other V4 countries) and the worse-affected Western European states. Nonetheless, other potential explanations need also to be considered. In particular, contextual and pre-existing structural factors could have played a role in slowing down the progress of the initial phases of the pandemic, limiting its adverse impact on the Polish population.

First, the demographic structures of the Central and Western European populations are different. This is particularly true for Poland and Slovakia, which have younger populations than many of Western European states. The proportion of the population aged sixty-five and over is $16 \%$ in Slovakia and $17.7 \%$ in Poland. ${ }^{54}$ On the other hand, in Germany it is $21.5 \%$, in France $20.1 \%$, in Spain $19.4 \%$ and in the UK

52 For details, see European Parliament, Uncertainty/EU/Hope. Public Opinion in the Time of Covid-19 (Brussels, 2020).

53 IHME, "COVID-19 Projections", available at <http://www.healthdata.org $>$.

54 The corresponding figure for Hungary is $19.3 \%$ and for Czechia is $19.6 \%$, see Eurostat, "Share of population aged 65 and over compared to the total population" (last updated 3 July 2020), available at $<$ https://ec.europa.eu/eurostat/ databrowser/view/tps00028/default/table?lang=en $>$. 
$18.4 \% .{ }^{55}$ While demographic structure does not have any impact on the spread of the disease, it may have a direct bearing on the number of severe COVID-19 cases and deaths, which are higher among older age groups. ${ }^{56}$

Second, there are significant differences in population density and connectivity. Poland has a higher proportion of its population living in rural areas as compared to most Western European countries, with only one city of over one million inhabitants and few metropolitan areas. The average share of the rural population in the EU is $25.27 \%$. This figure is much higher in Poland and currently stands at almost $40 \%$. On the other hand, Western European countries are well below this average, with Germany at 23\%, France and Spain at $19 \%$ and the UK at only $16 \% .{ }^{57}$ Equally, Poland has weaker connectivity, both within the country as well as with the external world. For example, the largest airport in Poland was ranked in thirty-third place in Europe in 2019 by passengers, just after London Luton Airport. ${ }^{58}$ The same is true for public transport between Polish cities and villages, which is less developed than in most Western European countries, forcing people to use private cars. Traffic, as measured in train kilometres in 2017, was 283.2 million (Poland), while in France it was 458.3 million, in Germany it was 1.1 billion and in the UK it was 566.5 million. ${ }^{59}$ Early research clearly indicates a correlation between density and connectivity and spread of disease, as dense/well-connected areas encourage more face-to-face interactions. ${ }^{60}$

Third, cultural factors relating to the character and intensity of social interactions also could be important. In general, Poles remain less mobile, both domestically and internationally, than their Western European peers. They tend to spend their time either at work or at home (including their free time). For example, in 2018, as many as $24 \%$ of Poles did not visit any restaurants, $44 \%$ did not go to the cinema and $55-74 \%$ did not attend any concerts or sport or theatre events. ${ }^{61}$ Social contacts are mainly limited to families, friends and co-workers. Polish society also retains the custom of caring for the elderly at home rather than in nursing and care homes (which constituted the epicentres of COVID-19 infections in many Western European countries, including in France and Spain). ${ }^{62}$ For example, according to the latest available data Poland has only 255 beds in nursing and residential care facilities per

\footnotetext{
55 ibid.

56 See, eg, Z Shahid et al, "COVID-19 and older adults: what we know" (2020) 68(5) Journal of the American Geriatrics Society 926.

57 World Bank, "Rural population (\% of total population) - European Union (2019)", available at <https://data. worldbank.org/indicator/SP.RUR.TOTL.ZS?locations=EU>.

58 See the list of the busiest airports complied by Wikipedia, available at $<$ https://en.wikipedia.org/wiki/List_of_the_ busiest_airports_in_Europe $>$.

59 European Commission, Statistical Pocket Book 2019: EU Transport in Figures (Luxembourg, Publications Office of the European Union 2019) p 74.

60 S Hamidi, S Sabouri and R Ewing, "Does density aggravate the COVID-19 pandemic?" (2020) 86(4) Journal of the American Planning Association 495; S Copiello and C Grillenzoni, "The spread of 2019-nCoV in China was primarily driven by population density. Comment on 'Association between short-term exposure to air pollution and COVID-19 infection: Evidence from China' by Zhu et al” (2020) 744 Science of the Total Environment 141028.

61 CBOS, Aktywność i doświadczenia Polaków w 2018 roku [Activities and experiences of Poles in 2018], Report No. 20/2019, available at <https://www.cbos.pl/SPISKOM.POL/2019/K_020_19.PDF>.

62 A Comas-Herrera et al, "Mortality associated with COVID-19 outbreaks in care homes: early international evidence”, LTCcovid.org, International Long-Term Care Policy Network, CPEC-LSE, 26 June 2020.
} 
100,000 of the population. The average for the EU is 848 beds per 100,000 of the population, with the figure in France being as high as $994 .^{63}$

It has also been suggested that the significant differences between the countries may be a consequence of different genomic variations of SARS-CoV-2 prevailing in specific regions. ${ }^{64}$ While there is no evidence to confirm this theory (during the period under investigation), it should be noted that in Europe several similar variants of the virus were dominant in the first phase of the pandemic. ${ }^{65}$ Moreover, the first Polish cases of SARS-CoV-2 were imported from Italy and Germany. Finally, it was hypothesised that the existence of compulsory bacillus Calmette-Guérin (BCG) vaccination programmes in certain countries may have slowed down the spread of COVID-1966 and decreased the chances of severe COVID-19 cases, thus lowering the mortality rate. ${ }^{67}$ Poland has had such a vaccination programme in place since the early 1950 s. The relevant research is, however, still at the preliminary stage, and the results remain contradictory. ${ }^{68}$

Arguably, some of these elements (ie population density/connectivity and cultural factors) could have slowed down the spread COVID-19 in the Polish population, limiting the number of new infections, helping to flatten the curve and preventing deaths in overloaded hospitals. These need further scholarly scrutiny. However, the importance of regulatory factors is apparent in developments observed in Poland and other V4 countries in the later stages of the COVID-19 pandemic.

As of 19 October 2021, Poland had 2,945,056 registered COVID-19 cases and 76,179 COVID-19-related deaths. This put Poland at the top of the most affected countries in the world (currently ranking sixteenth). The number of infections started to grow rapidly in October 2020 and reached 20,000 cases per day by the end of the month. In early November, Poland surpassed Spain and the UK in daily new confirmed cases of COVID-19 per million inhabitants (as a rolling seven-day average). ${ }^{69}$ After a drop in the number of infections at the beginning of 2021, the number started to grow again, reaching yet another peak in March. In fact, all of the V4 countries have seen an unprecedented acceleration in infections between autumn 2020 and spring 2021.

Given these developments, it is important to ask why we observed such a huge change in the impact of the pandemic in Poland, from a relatively well-contained initial phase to rapid growth, especially as all of the contextual and structural factors (ie demographic structure, population density/connectivity and cultural factors) remained in place.

63 WHO-Europe, "Beds in nursing and residential care facilities, per 100 000", available at <https://bit.ly/ 3 myfWIC $>$.

64 See, eg, Y Toyoshima et al, "SARS-CoV-2 genomic variations associated with mortality rate of COVID-19" (2020) 65 Journal of Human Genetics 1075.

65 SK Biswas and SR Mudi, "Genetic variation in SARS-CoV-2 may explain variable severity of COVID-19", (2020) 143 Medical Hypotheses 109877.

66 MK Berg et al, "Mandated bacillus Calmette-Guérin (BCG) vaccination predicts flattened curves for the spread of COVID-19" (2020) 6(32) Science Advances eabc1463.

67 D Klinger et al, "Significantly improved COVID-19 outcomes in countries with higher BCG vaccination coverage: a multivariable analysis" (2020) 8(3) Vaccines 378.

68 U Hamiel, E Kozer and I Youngster, "SARS-CoV-2 rates in BCG-vaccinated and unvaccinated young adults" (2020) 323(22) JAMA 2340.

69 “Coronavirus Pandemic (Covid-19)", Our World in Data, available at <https://ourworldindata.org/coronavirus > 
What has changed, however, are three regulatory components (discussed above) that characterised the initial, successful response to COVID-19 in Poland.

As indicated earlier, most of the restrictions in Poland were either withdrawn or watered down between May and June 2020. Those changes were necessary to restart the economy and limit the associated economic crisis. There were also political reasons for loosening these measures. According to the electoral calendar, the presidential elections were planned for 10 May 2020. The ruling party Prawo $i$ Sprawiedliwość (Law and Justice, PiS) was committed to maintaining that date. Eventually, due to opposition from one of their coalition partners, the date was postponed to 28 June 2020. Political analysts speculated that the attempts of PiS to create an appearance of a "return to normality" by quickly dismantling pandemic control measures was a political decision to increase the popularity of the incumbent president ahead of the vote. Indeed, in June 2020, Prime Minister Mateusz Morawiecki declared at a rally: "I am glad that we are less and less afraid of this virus, this epidemic. This is a good approach because it is on the retreat. You don't need to be afraid of it now. You have to go to the elections on July 12 [NB: when the second round of the elections took place - the authors]. Everyone, especially seniors, do not be afraid, go to the elections". ${ }^{70}$ Similar opinions were expressed by other senior figures from the ruling coalition, including the head of the ruling party. ${ }^{71}$ Some experts actually warned that the sanitary regime was being loosened too quickly. ${ }^{72}$ Indeed, although no sharp increase in the number of new cases was observed immediately after the completion of the four phases of easing of the restrictions (as well as after the presidential election), the number of daily cases stabilised at a higher level (between 200 and 600) than in most Western European countries. During that period, the GRSI for Poland decreased from 83.33 points (April-May 2020) to just 39.81 (10 July 2020), and this figure declined further in September 2020 to only 19.44. Most Western European countries have retained a more stringent regime. For example, the lowest value recorded for France was 38.34, for Germany it was 46.76 and for Spain it was 39.35, while for the UK it was 60.19.

As the number of cases began to grow again in Poland in September 2020, restrictions were reintroduced. However, this was done more slowly than in other EU countries, and much more slowly than during the first phase of the pandemic. The first substantial measures were taken only on 8 October 2020 when the government, among other things, classified the whole country (as of 10 October) as a yellow zone. Such requalification resulted in a number of new, minor restrictions pertaining to public

\footnotetext{
70 "Premier: Już nie trzeba się bać wirusa. Trzeba tłumnie pójść na wybory” [The Prime Minister: You don’t need to be afraid of the virus. You should all participate in the elections] (Do Rzeczy, 1 July 2020), available at <https://bit.ly/ $2 \mathrm{TMzGvD}>$. Note that senior voters constitute an important part of the base of PiS.

71 See, eg, “Nie ma się czego obawiać'. Prezes PiS zachęca seniorów do udziału w wyborach” ["There is nothing to be afraid of". The head of PiS encourage seniors to participate in the elections] (Polskie Radio 24, 10 July 2020), available at $<$ https://bit.ly/3oSpbp2 $>$.

72 See, eg, the interviews with Dr Tomasz Dzieciątkowski (TVN24, 29 April 2020, <https://bit.ly/362rHAe >), Prof. Małgorzata Jacyno (Tok FM, 23 May 2020, <https://bit.ly/35XF057>), Prof. Krzysztof Simon (Pacjenci.pl, 17 July 2020, <https://bit.ly/3kUPPLs>) and Prof. Anna Boroń-Kaczmarska (Interia, 24 October 2020, <https://bit.ly/ 34TGcas $>$ ).
} 
transport, the operation of service outlets, public gatherings, etc. ${ }^{73}$ On the day that these measures were announced, Poland reported 4280 new cases and 76 COVID-19-related deaths. Another package of measures was introduced on 23 October 2020, when the whole country was classified as a red zone (meaning, for example, obligatory face masks in all public places). ${ }^{74}$ On the same day, Poland saw 13,632 new cases and 153 COVID-19-related deaths. The process of strengthening the Polish sanitary regime is reflected in the GRSI. The index increased from 33.33 on 10 October 2020 to 71.30 on 23 October. This time, however, Poland was behind other EU countries. Although the countries of Western Europe introduced restrictions at about the same time as Poland, they moved from a much higher base (all of them above 40 points and in some cases above 60 points).

The adherence of Poles to public health measures has also deteriorated over the summer. A growing number of people questioned the effectiveness of these measures or the seriousness of the situation. In one survey (22-24 September 2020), only 53\% of respondents considered the epidemic to be a serious threat, 55\% believed that everyone should comply with face mask requirements and social distancing measures and only $26 \%$ were planning on getting vaccinated against COVID-19. ${ }^{75}$ Poland was not the only European country to experience what has been termed "pandemic fatigue". ${ }^{76}$ However, the decline in adherence in Poland appears to be more significant than in other EU countries. Again, the face mask mandate may serve as a good example. The government initially introduced it on 16 April 2020 and significantly modified it on 30 May by loosening the applicable restrictions. According to the revised rules, face masks were still mandatory in closed spaces (eg public transport, shops, churches), but in open spaces only if achieving two meters of social distance was not possible. At the same time, the adherence rate had started to decline on 30 April 2020, and within a month it fell from $78 \%$ to $60 \%$. By 6 July 2020 , only $37 \%$ of the population was using face masks, and this trend was only reversed on 5 October 2020. This is a significantly lower figure than in many Western European countries. For example, Spain saw an adherence level of above $80 \%$ for most of July and August, while Germany maintained a consistent $50 \%$ adherence level throughout this period. It is also likely that, in addition to waning enthusiasm, Poles were discouraged from following the rules due to the narrative of the Polish government before the presidential election in June and July 2020 and afterwards. Note that the government maintained until the end of September 2020 the narrative of a successful management of the pandemic. For example, the Polish President, in an interview given on 25 September 2020 (just eleven days before the

\footnotetext{
73 "Epidemia koronawirusa - lepsza koordynacja działań i nowe zasady bezpieczeństwa rozszerzone na cały kraj" [Coronavirus epidemic - better coordination of activities and new safety rules extended to the whole country] (Gov.pl, 8 October 2020), available at <https://bit.ly/32geId6 > .

74 "Cała Polska w czerwonej strefie, kolejne zasady bezpieczeństwa oraz Solidarnościowy Korpus Wsparcia Seniorów" [Whole Poland in a red zone. Additional safety measures and the Solidarity Assistance Corps for the Seniors] (Gov.pl, 23 October 2020), available at <https://bit.ly/32fK5V4>.

75 See Inquiry \& YouGov, "Epidemia Covid-19: Badanie postaw Polaków” [Covid-19 epidemic: attitudes of Poles], available at $<$ https://inquirymarketresearch.pl/covid-tracker/>.

76 WHO (Regional Office for Europe), Pandemic Fatigue. Reinvigorating the Public to Prevent COVID-19 (Copenhagen, 2020). See also JFA Murphy, "Pandemic fatigue" (2020) 113(6) Irish Medical Journal 90.
} 
first sharp increase in the number of cases), said that "the pandemic is not in retreat, but it is under control in our country ... [T]here is an increase in infections, but we still control this pandemic, there is no risk of an explosion today, there is an increase that was expected and we can probably expect some further increase by mid-October". ${ }^{77}$ Such reassuring opinions were not uncommon among governmental officials, including the Minister of Health. ${ }^{78}$ There is ample evidence that consistency in risk communication influences popular risk perception. ${ }^{79}$ At the same time, people with a higher perception of risk are more likely to adopt preventative measures and to adhere to rules. ${ }^{80}$

Poland's experience in the later phase of the COVID-19 pandemic was therefore drastically different from its successful initial management of the disease, despite the underlying structural and contextual factors remaining unchanged. Meanwhile, the public health measures became more lax and were adopted more slowly, and the level of adherence to them was lower than in the spring of 2020.

\section{Conclusion: what lessons can be Learned from the Polish experience?}

This article recognises that the observed differences between countries in the progression of the COVID-19 pandemic are the result of a multitude of complex and interrelated reasons, including structural, pre-existing factors. At the same time, it argues that the design and timing of regulatory responses, as well as the adherence of the population, can have crucial impacts on the number of infections and COVID-19-related deaths, as the example of Poland shows.

Those elements (or the lack of them) can also explain, at least partially, the public health crisis that occurred in Poland during the second phase of the COVID-19 epidemic. In particular, it is argued that the health restrictions have been too lenient for this stage of the pandemic and that they were adopted too late, while the level of adherence with relevant rules by Poles has been lower than in the spring of 2020.

In a situation where there is widespread misinformation, the Polish case study provides a valuable practical illustration of certain characteristics of infectious disease epidemics that, while well known to public health professionals, have been questioned by others during the pandemic. First, it is possible to reduce transmission using well-designed public health measures enacted by governments. Contrary to what some argue, these measures are not at all futile. Second, they should be implemented early. This is a simple mathematical fact when faced with exponential growth, yet, too often,

\footnotetext{
77 "Pandemic is under control in Poland: President" (PolandIn, 25 September 2020), available at <https://bit.ly/ 2GxFTIX > .

78 See, eg, "Niedzielski: Epidemia koronawirusa ustabilizowała się, ale to nie jej koniec" [Niedzielski: Coronavirus epidemic has stabilized but it is not over yet] (Gazeta Prawna, 14 September 2020), available at <https://bit.ly/ 35YBUh6>.

79 See, eg, GM Breakwell, "Risk communication: factors affecting impact" (2000) 56(1) British Medical Bulletin 110,116 . The WHO also indicated delivering a consistent message as an important element that affects successful risk communication: see WHO, WHO Strategic Communications Framework for Effective Communications (Geneva, WHO Press 2017) p 17.

80 See, eg, J Xu and Z Peng, "People at risk of influenza pandemics: the evolution of perception and behavior" (2015) 10(12) PLoS ONE e0144868; X Wang et al, "Risk communication on behavioral responses during COVID-19 among general population in China: a rapid national study" (2020) 81(6) Journal of Infection 911.
} 
governments have delayed. Third, and linked to the second point, agility is important. A proactive strategy that anticipates and reacts quickly to changing circumstances produces better results than a strategy based on incremental steps that are stretched out over time. Fourth, the precautionary principle applies, pointing to the importance of action even where there is uncertainty. This is especially so for those measures that impose minimal cost and risk (eg mandatory face masks in public places), even if others (eg border closures) require more deliberation. Fifth, in seeking to understand why some countries have done better than others, all of these factors (ie design, timing and adherence) should be considered.

While each country is different, some of the characteristics of the Polish response can be seen in the other V4 countries, each showing similarities in the progression of the pandemic. The numbers of COVID-19 cases and related deaths in the first phase of the pandemic throughout the region were low. None of these countries experienced rapid and prolonged exponential growth in infections. Their regulatory responses were also similar - each government decided to intervene early and introduced very strict measures. Moreover, all of these countries are similar in terms of their demographic structure, population density and culture - the elements that we classified as the contextual and structural factors. Nevertheless, before making any definitive conclusions, additional empirical research is needed in these countries. This article may provide an appropriate conceptual framework that could be used for such analyses. 